\title{
Profil Pengetahuan Vitamin untuk Pencegahan COVID-19 pada Pekerja Industri di Kota Cilegon
}

\author{
Salsabila, Liza Pristianty, Abdul Rahem, Yuni Priyandani* \\ Fakultas Farmasi Universitas Airlangga, Surabaya, Jawa Timur, Indonesia. \\ *E-mail: yuni-p@ff.unair.ac.id
}

(Submit 19/12/2021, Revisi 20/12/2021, Diterima 30/12/2021, Terbit 31/12/2021)

\begin{abstract}
Abstrak
Latar belakang: Banyaknya industri di Kota Cilegon yang tetap beroperasi saat pandemi corona virus disease 2019 (COVID-19) membuat pekerja industri harus tetap pergi bekerja sehingga berpotensi tertular. Usaha pencegahan infeksi COVID-19 dilakukan dengan penerapan protokol kesehatan dan peningkatan sistem imun. Peningkatan penjualan vitamin B, C, D, dan E hingga tiga kali lipat selama pandemi menandakan bahwa masyarakat berusaha berperilaku untuk meningkatkan sistem imun. Pengetahuan merupakan tahap awal seseorang dalam menerima stimulus baru yang akan menentukan sikap dan tindakan dalam berperilaku. Tujuan: Penelitian ini bertujuan mengetahui profil pengetahuan tentang vitamin sebagai peningkat sistem imun untuk pencegahan COVID-19 pada pekerja industri di Kota Cilegon. Metode: Desain penelitian merupakan observasional secara cross sectional dengan teknik accidental sampling dan snowball sampling. Penelitian ini mendapatkan keterangan layak etik dari Komisi Etik Fakultas Farmasi Universitas Airlangga. Penelitian dilakukan pada 100 responden pekerja industri pada bulan Mei sampai Juni 2021 di Kota Cilegon. Responden diberikan instrumen kuesioner secara daring (online) dengan Google Form. Instrumen kuesioner terdiri tiga indikator yaitu pengetahuan tentang COVID-19, pengetahuan tentang sistem imun, dan pengetahuan tentang vitamin sebagai peningkat sistem imun untuk pencegahan COVID-19. Analisis data dilakukan dengan Statistical Package for Social Science (SPSS) versi 25. Hasil: Analisis data menunjukkan 1\% responden memiliki pengetahuan rendah, 32\% responden berpengetahuan sedang, dan $67 \%$ responden berpengetahuan tinggi. Kesimpulan: Pengetahuan pekerja industri di Kota Cilegon tentang vitamin sebagai peningkat sistem imun untuk pencegahan COVID-19 menunjukkan hasil pengetahuan tinggi.
\end{abstract}

Kata Kunci: pengetahuan, vitamin, sistem imun, COVID-19, pekerja industri 


\section{Pendahuluan}

Pada akhir Januari 2020, WHO menetapkan status global emergency pada kasus COVID-19 dikarenakan proses penularan yang sangat cepat. COVID-19 ini berawal dari kota Wuhan di Cina pada tahun 2019. COVID-19 disebabkan oleh virus yang tergolong dalam genus betacoronavirus. Coronavirus merupakan virus RNA strain tunggal positif, berkapsul dan tidak bersegmen (1). Patogenesis infeksi COVID-19 belum diketahui seluruhnya. COVID-19 awalnya diperkirakan menular hanya lewat droplet virus kontak dengan mukosa yang terbuka pada hidung, mulut, atau mata (2), sekarang diperkirakan penularan bisa melalui udara ${ }^{(3)}$.

Klasifikasi infeksi COVID-19 menurut buku Pedoman Pencegahan dan Pengendalian Coronavirus Disesase (COVID-19) revisi 5 per 13 Juli 2020 yaitu kasus suspek, kasus probable, kasus konfirmasi, kontak erat, pelaku perjalanan, discarded, dan kasus kematian. Berdasarkan data Kementerian Kesehatan Republik Indonesia, hingga tanggal 3 Oktober 2020, kasus konfirmasi COVID-19 di dunia sebanyak 34.396.222, kasus meninggal sebanyak 1.024 .675 pada 179 negara yang terjangkit COVID-19. Sedangkan di Indonesia, ada 2.074.943 kasus dengan specimen diperiksa dengan 1.775.437 adalah kasus negatif, kasus terkonfirmasi sebanyak 299.506, kasus meninggal 11.055, kasus sembuh 225.052, kasus aktif 63.399, dan kasus suspek 139.099 (4).

Masyarakat perlu melakukan upaya pencegahan COVID-19 karna hingga saat ini belum ditemukan pengobatan definitif untuk COVID-19. Berdasarkan keputusan menteri kesehatan Republik Indonesia NOMOR HK.01.07/MENKES/382/2020 tahun 2020 tentang protokol kesehatan bagi masyarakat di tempat dan fasilitas umum dalam rangka pencegahan dan pengendalian corona virus disease 2019 (COVID-19) (5), protokol kesehatan individu secara umum yaitu menggunakan masker sebagai alat pelindung diri membersihkan tangan secara teratur menjaga jarak minimal 1 meter dengan orang lain, dan meningkatkan sistem imun yang dapat dilakukan dengan cara menghindari stress, berolahraga rutin, menghindari rokok dan alkohol, mengkonsumsi buah dan sayur, serta mengonsumsi suplemen atau vitamin(6).

Vitamin B, C, D, dan E diketahui memiliki efek positif dalam sistem imun dalam upaya pencegahan COVID-19. Penelitian Hira et al. menyatakan bahwa Vitamin B membantu aktivasi yang tepat dari respon imun bawaan dan adaptif, mengurangi pro-inflamasi tingkat sitokin, meningkatkan fungsi pernafasan, mempertahankan endotel integritas, mencegah hiperkoagulabilitas dan dapat mengurangi lama tinggal di rumah sakit(7). Anita I dan Yuke A (8) menyatakan bahwa Vitamin $\mathrm{C}$ memiliki aktivitas antioksidan dan dapat mengurangi stres oksidatif dan peradangan, efek yang meningkatkan sintesis vasopresor, meningkatkan fungsi sel kekebalan tubuh, meningkatkan fungsi endovaskular, dan menyediakan modifikasi imunologis epigenetic ${ }^{(9)}$. Sumber vitamin C bisa didapat dari jeruk, pisang, tomat, paprika, blewah, bayam, kol, kentang, kacang, hijau, serta suplemen vitamin $C^{(10)}$. Batas penggunaan maksimal harian vitamin $C$ adalah $1000 \mathrm{mg}{ }^{(10)}$. terapat beberapa literature yang mengemukakan mekanisme vitamin $D$ dalam mengurangi resiko infeksi virus ${ }^{(11-15)}$. Menurut Martha $A^{(16)}$, vitamin $D$ 
dapat meningkatkan sistem imun dan menurunkan resiko infeksi dengan mekanisme induksi cathelicidin dan defensin yang mampu menurunkan laju replikasi virus dan menurunkan konsentrasi sitokin proinflamasi. Vitamin $D$ terbentuk pada kulit dengan bantuan sinar UV B dari sinar matahari lalu diubah menjadi bentuk aktif yaitu kalsitriol di ginjal $^{(17)}$. Sumber vitamin D didapat dari ikan tuna, salmon, telur, hati sapi, keju, jamur, dan suplemen vitamin $D^{(18)}$. Batas maksimal penggunaan vitamin $D$ dalam satu hari yaitu $400 \mathrm{IU}^{(18)}$. Dalam pembentukan antibodi, vitamin $\mathrm{E}$ dapat menekan respon Th2. Vitamin $E$ membantu membentuk sinapsis imun yang efektif antara sel Th; meningkatkan proporsi antigen pada sel T memori yang telah terbentuk sebelumnya(8). Sumber vitamin $\mathrm{E}$ bisa didapatkan dari tauge, minyak jagung, margarin, minyak kelapa sawit, serta suplemen vitamin $E^{(19)}$. Maksimal penggunaan harian vitamin $E$ adalah 400 IU(19).

Kota Cilegon dikenal sebagai kota perindustrian dan merupakan pusat kegiatan industri pengolahan di Banten bagian barat. Kota Cilegon juga dikenal sebagai kota baja karna adanya industri baja terbesar di Indonesia (20). Kemudian, sekitar $80 \%$ industri kimia nasional terdapat di Kota Cilegon (21). Banyaknya industri di Kota Cilegon yang tetap beroperasi saat COVID-19 membuat karyawan harus tetap pergi bekerja sehingga dapat meningkatkan resiko tertular infeksi virus COVID-19. Meskipun perusahaan sudah mengatur protokol kesehatan saat bekerja, namun para pekerja harus tetap menjaga daya tahan tubuhnya dengan menambah asupan vitamin. Pengetahuan merupakan tahap awal seseorang dalam menerima stimulus baru yang akan menentukan sikap dan tindakan seseorang dalam berperilaku sehat (22). Setelah pandemik COVID-19, penjualan vitamin pada bulan Februari hingga April 2020 meningkat hingga tiga kali lipat dari sebelumnya menandakan bahwa masyarakat berupaya menjaga daya tahan tubuh saat pandemik COVID-19 dengan mengonsumsi vitamin (23). Tindakan masyarakat mengonsumsi vitamin tersebut dilandasi oleh pengetahuan. Oleh karena itu, penelitian ini bertujuan untuk mengetahui profil pengetahuan tentang vitamin sebagai peningkat sistem imun untuk upaya pencegahan COVID-19 pada pekerja industri di Kota Cilegon.

\section{Metode}

\section{Desain Penelitian}

Desain yang digunakan adalah penelitian observasional. Peneliti tidak memberikan perlakuan atau intervensi kepada subjek penelitian, hanya mengamati kejadian atau fenomena yang telah ada dan diduga terdapat hubungan sebab-akibat. Dengan pendekatan cross sectional yaitu variabel dependen dan independen diteliti dalam satu waktu (24).

Pengambilan sampel pada penelitian ini dilakukan dengan non random sampling dengan teknik accidental yaitu pengambilan sampel yang kebetulan tersedia dan teknik snowball yaitu pengambilan sampel dari yang awalnya berjumlah sedikit menjadi banyak (25). Kriteria reponden pada penelitian ini antara lain usia $\geq 18$ tahun dan dalam keadaan sehat, pekerja industri di Kota Cilegon, berdomisili di Kota Cilegon, mampu menggunakan smartphone dan internet, serta bukan pekerja industri dengan latar pendidikannya dibidang kesehatan di Kota Cilegon. 


\section{Instrumen survey}

Penelitian dilakukan pada 100 responden pekerja industri pada bulan Mei sampai Juni 2021 di Kota Cilegon. Responden diberikan instrumen kuesioner secara daring (online) dengan Google Form dan sudah mendapatkan keterangan layak etik dari Komisi Etik Fakultas Farmasi Universitas Airlangga. Dalam Google Form terdapat lembar informasi, lembar persetujuan menjadi responden, dan lembar kuesioner. Lembar informasi dalam penelitian ini untuk responden yang berisi tentang prosedur penelitian, sehingga responden mengetahui apa yang akan dilakukan ketika ikut serta dalam penelitian. Lalu terdapat lembar persetujuan menjadi responden diisi setelah membaca lembar informasi. Lembar ini digunakan sebagai bukti kesediaan responden untuk mengikuti prosedur penelitian. kemudian ada lembar data demografi berisi pertanyaan mengenai usia, jenis kelamin, pendidikan terakhir, dan jabatan responden. Terakhir ada lembar kuesioner berisi pernyataan-pernyataan yang dapat digunakan untuk mengukur tingkat pengetahuan responden.

Pada lembar kuesioner terdapat 15 pernyataan yang berisi pernyataan positif dan negatif untuk melihat pengetahuan responden terkait vitamin sebagai peningkat sistem imun untuk pencegahan COVID-19 dengan nilai skor untuk jawaban tepat $=1$ dan jawaban tidak tepat $=0$. Pernyataan positif adalah pernyataan yang jawabannya benar dan penyataan negative adalah penyataan yang jawabannya salah. Penelitian ini menggunakan analisis data deskriptif. Data yang terkumpul diolah dan digambarkan dalam bentuk frekuensi dan persentase. Analisis data dilakukan dengan menghitung jumlah benar dari hasil kuesioner lalu dikelompokkan menjadi tiga kategori yaitu rendah, sedang, dan tinggi. Analisis data dilakukan dengan Statistical Package for Social Science (SPSS) versi 25.

\section{Hasil}

\section{Uji Validitas dan Reliabilitas}

Kuesioner dalam penelitian ini dilakukan uji validitas dan reliabilitas pada masyarakat Kota Surabaya yang berusia di atas 18 tahun. Uji validitas isi dilakukan dengan mencari pustaka yang sesuai dari pernyataan dalam kuesioner dan dikonfirmasi oleh ahli yang dalam hal ini yaitu dosen pembimbing serta komisi etik. Uji validitas rupa dilakukan dengan meminta kritik dan saran dari responden mengenai kuesioner, didapatkan 3 orang memberi kritik dan saran pada tata bahasa kuesioner sehingga lebih mudah dipahami. Kemudian dilakukan uji validitas konstruk dilakukan pada 50 responden lalu didapatkan hasil berupa $r$ hitung. $R$ hitung lebih dari $r$ tabel maka kuesioner dinyatakan valid. Dari tabel 1 menunjukkan $r$ hitung lebih dari $r$ tabel sehingga dapat disimpulkan kuesioner valid. 
Tabel 1. Hasil uji validitas kuesioner

\begin{tabular}{|c|c|c|c|}
\hline Pernyataan & $\begin{array}{c}\text { rhitu } \\
\text { ng }\end{array}$ & $\begin{array}{l}\text { rtabe } \\
\text { । }\end{array}$ & Validitas \\
\hline 1 Covid-19 merupakan penyakit yang disebabkan oleh Virus korona jenis baru yang disebut Sars & 0.41 & 0.27 & Valid \\
\hline CoV-2. & 2 & 9 & \\
\hline \multirow[t]{2}{*}{2 Penularan Covid-19 dapat terjadi melalui kontak fisik, tetesan droplet, dan kontak udara. } & 0.42 & 0.27 & Valid \\
\hline & 5 & 9 & \\
\hline \multirow{4}{*}{$\begin{array}{l}3 \text { Pencegahan Covid-19 dapat dilakukan melalui berolahraga secara teratur, perilaku hidup } \\
\text { bersih dan sehat, serta memenuhi kebutuhan vitamin. } \\
4 \text { Sistem daya tahan tubuh dapatan adalah sistem daya tahan tubuh yang sudah ada sejak lahir. }\end{array}$} & 0.36 & 0.27 & Valid \\
\hline & 5 & 9 & \\
\hline & 0.39 & 0.27 & Valid \\
\hline & 0 & 9 & \\
\hline \multirow{4}{*}{$\begin{array}{l}5 \text { Sistem daya tahan tubuh seseorang dapat bekerja terhadap benda asing seperti bakteri, } \\
\text { jamur, maupun virus Covid-19. } \\
6 \text { Peningkatan sistem daya tahan tubuh dapat mencegah terjadinya infeksi Covid- } 19 \text {. }\end{array}$} & 0.60 & 0.27 & Valid \\
\hline & 5 & 9 & \\
\hline & 0.42 & 0.27 & Valid \\
\hline & 9 & 9 & \\
\hline \multirow[t]{2}{*}{7 Memenuhi kebutuhan Vitamin dapat meningkatkan daya tahan tubuh. } & 0.62 & 0.27 & Valid \\
\hline & 9 & 9 & \\
\hline \multirow[t]{2}{*}{8 Vitamin merupakan kebutuhan yang tidak harus dipenuhi oleh tubuh dalam jumlah yang cukup. } & 0.41 & 0.27 & Valid \\
\hline & 8 & 9 & \\
\hline \multirow{4}{*}{$\begin{array}{l}9 \text { Vitamin yang dapat meningkatkan sistem daya tahan tubuh untuk pemeliharaan kesehatan di } \\
\text { era Covid-19 yaitu Vitamin B, C, D, dan E. } \\
10 \text { Kekurangan Vitamin B dapat mengakibatkan gangguan saluran pernafasan. }\end{array}$} & 0.38 & 0.27 & Valid \\
\hline & 9 & 9 & \\
\hline & 0.35 & 0.27 & Valid \\
\hline & 9 & 9 & \\
\hline \multirow[t]{2}{*}{11 Vitamin B dapat melindungi dari infeksi Covid-19. } & 0.39 & 0.27 & Valid \\
\hline & 5 & 9 & \\
\hline \multirow[t]{2}{*}{12 Vitamin C bekerja sebagai antioksidan sehingga dapat mencegah terjadinya infeksi Covid-19. } & 0.49 & 0.27 & Valid \\
\hline & 4 & 9 & \\
\hline \multirow[t]{2}{*}{13 Dosis harian Vitamin C untuk pemeliharaan kesehatan maksimal $1000 \mathrm{mg} / \mathrm{hari}$} & 0.36 & 0.27 & Valid \\
\hline & 8 & 9 & \\
\hline \multirow[t]{2}{*}{14 Vitamin E dapat bekerja pada sistem daya tahan tubuh saat terinfeksi Covid-19. } & 0.45 & 0.27 & Valid \\
\hline & 2 & 9 & \\
\hline \multirow[t]{2}{*}{15 Vitamin D tidak dapat melindungi paru dari infeksi Covid-19. } & 0.52 & 0.27 & Valid \\
\hline & 1 & 9 & \\
\hline
\end{tabular}

Selanjutnya dilakukan uji reliabilitas menggunakan hasil dari responden yang sama dengan responden pada uji validitas. Uji reliabilitas menggunakan alpha cronbach sebagai penentu reliabilitas kuesinoner dengan bantuan software Statistical Package for Social Science (SPSS) Versi 25. Hasil uji reliabilitas dari 15 butir pernyataan yang telah valid menunjukkan alpha cronbach sebesar 0.684 yang berarti bahwa alpha cronbach lebih dari 0.6 sehingga dapat disimpulkan kuesioner reliabel dan dapat digunakan sebagai instrument penelitian (26).

\section{Data Demografi Responden}

Dalam penelitian ini jenis kelamin responden terbanyak adalah laki-laki sebanyak $84 \%$. Responden dalam penelitian ini memiliki rentang umur dari 21 tahun hingga 62 tahun dengan latar belakang pendidikan terakhir sebanyak 50\% adalah sarjana. 58\% responden memiliki jabatan sebagai staff dengan domisili terbanyak adalah kecamatan Cilegon yaitu sebanyak $25 \%$. Distribusi data demografi responden ditampilkan dalam tabel 2. 
Tabel 2. Data Demografi

\begin{tabular}{|c|c|c|c|}
\hline Demografi & Keterangan & Frekuensi (n) & Persentase (\%) \\
\hline \multirow[t]{2}{*}{ Jenis Kelamin } & Laki-Laki & 84 & 84 \\
\hline & Perempuan & 16 & 16 \\
\hline \multirow[t]{5}{*}{ Umur } & $18-25$ & 35 & 35 \\
\hline & $26-35$ & 24 & 24 \\
\hline & $36-45$ & 17 & 17 \\
\hline & $46-55$ & 21 & 21 \\
\hline & $56-65$ & 3 & 3 \\
\hline \multirow[t]{3}{*}{ Pendidikan terakhir } & SMA/Sederajat & 35 & 35 \\
\hline & Diploma & 15 & 15 \\
\hline & Sarjana & 50 & 50 \\
\hline \multirow[t]{6}{*}{ Jabatan } & Teknisi & 5 & 5 \\
\hline & Staf & 58 & 58 \\
\hline & Supervisor & 11 & 11 \\
\hline & Manager & 21 & 21 \\
\hline & Direktur & 3 & 3 \\
\hline & Direktur Utama & 2 & 2 \\
\hline \multirow[t]{8}{*}{ Domisili (Kecamatan) } & Cibeber & 13 & 13 \\
\hline & Cilegon & 25 & 25 \\
\hline & Citangkil & 15 & 15 \\
\hline & Ciwandan & 10 & 10 \\
\hline & Grogol & 8 & 8 \\
\hline & Jombang & 11 & 11 \\
\hline & Pulomerak & 3 & 3 \\
\hline & Purwakarta & 15 & 15 \\
\hline
\end{tabular}

\section{Pembahasan}

Pengetahuan merupakan hasil dari tahu dan terjadi setelah seseorang melakukan penginderaan terhadap suatu objek tertentu. Penginderaan dapat melalui panca indra manusia, yaitu penglihatan (mata), pendengaran (telinga), penciuman (hidung), rasa (lidah), dan raba (kulit). Sebagian besar pengetahuan manusia diperoleh melalui mata dan telinga. Pengetahuan merupakan tahap awal seseorang dalam menerima stimulus baru yang kemudian akan menentukan sikap dan tindakan seseorang dalam berperilaku sehat ${ }^{(22)}$.

Kuesioner penelitian ini dibagi menjadi tiga indikator yaitu pengetahuan tentang COVID19 , pengetahuan tentang sistem imun, dan pengetahuan tentang vitamin sebagai peningkat sistem imun untuk upaya pencegahan COVID-19. Pengetahuan tentang COVID-19 diperlukan agar responden mengetahui pencegahan yang diperlukan untuk menghadapi pandemik ini.

Pengukuran pengetahuan tentang covid terdapat pada pernyataan nomor 1 , 2, dan 3 . Hasil pengukuran pada pernyataan nomor satu adalah 93\% responden mengetahui bahwa Covid-19 merupakan penyakit yang disebabkan oleh virus corona jenis baru 
yang disebut Sars CoV-2. Coronavirus merupakan virus RNA strain tunggal positif, berkapsul dan tidak bersegmen (1). Hasil pengukuran pada penyataan nomor dua yaitu 94\% responden mengetahui bahwa penularan COVID-19 dapat terjadi melalui kontak fisik, tetesan droplet (pada jarak dekat), dan kontak udara serta 6\% responden tidak mengetahuinya. Hasil tersebut hampir menyamai hasil penelitian dari Jesica dan Rizma pada masyarakat Indonesia (2020) yaitu sebesar 96\% responden mengetahui cara penularan COVID-19(27). Responden pada penelitian ini memiliki pengetahuan tentang cara penularan COVID-19 lebih rendah dibanding penelitian dari Jesica dan Rizma pada masyarakat Indonesia (2020) (27). COVID-19 awalnya diperkirakan menular hanya lewat droplet virus kontak dengan mukosa yang terbuka pada hidung, mulut, atau mata (2), sekarang diperkirakan penularan bisa lewat udara (3). Untuk hasil pengukuran pada penyataan nomor tiga yaitu sebesar $98 \%$ responden mengetahui bahwa pencegahan COVID-19 dapat dilakukan melalui berolahraga secara teratur, perilaku hidup bersih dan sehat, serta memenuhi kebutuhan vitamin. Hasil ini selaras dengan hasil dari Jesica dan Rizma pada masyarakat Indonesia (2020) yaitu sebesar $78,5 \%-91,7 \%$ responden mengetahui cara pencegahan COVID-19(27). Hal tersebut menunjukkan responden pada penelitian ini pengetahuan cara pencegahan COVID-19 lebih tinggi daripada responden pada penelitian Jesica dan Rizma (2020) (27).

Indikator selanjutnya yaitu pengetahuan tentang sistem imun. $78 \%$ responden mengetahui bahwa sistem daya tahan tubuh dapatan bukan merupakan sistem daya tahan tubuh yang sudah ada sejak lahir, 91\% responden mengetahui bahwa sistem daya tahan tubuh seseorang dapat bekerja terhadap benda asing seperti bakteri, jamur, maupun virus Covid-19, dan 96\% responden mengetahui bahwa peningkatan sistem daya tahan tubuh dapat mencegah terjadinya infeksi Covid-19. Pada kondisi tubuh yang baik, reaksi imun alami dan reaksi imun adaptif bekerja untuk mempertahankan kekebalan tubuh. Sedangkan bila ditujukan untuk memperbaiki sistem kekebalan tubuh hanya diperlukan pada saat kondisi tubuh tidak dalam kondisi yang baik (28).

Indikator terakhir yaitu pengetahuan tentang vitamin sebagai peningkat sistem imun untuk upaya pencegahan COVID-19. 100\% responden mengetahui bahwa memenuhi kebutuhan vitamin dapat meningkatkan daya tahan tubuh, hasil ini selaras dengan penelitian yang dilakukan oleh dhiani et al. di TK Aisyiyah Ledug (2020) yaitu sebesar 93\% responden mengetahui tujuan dari penggunaan vitamin ${ }^{(29)}$. Dapat disimpulkan bahwa responden pada penelitian ini pengetahuan tentang vitamin dapat meningkatkan daya tahan tubuh lebih tinggi daripada responden pada penelitian dhiani et al. di TK Aisyiyah Ledug (2020) (29). 67\% responden mengetahui bahwa vitamin merupakan kebutuhan yang harus dipenuhi oleh tubuh dalam jumlah yang cukup. 95\% responden mengetahui bahwa vitamin yang dapat meningkatkan sistem daya tahan tubuh untuk pemeliharaan kesehatan di era COVID-19 yaitu vitamin B, C, $D$, dan E. Hasil tersebut menunjukkan bahwa sebagian besar responden mengetahui penggunaan obat tradisional atau suplemen kesehatan kebanyakan ditujukan untuk memelihara sistem kekebalan tubuh (28). 
Sebanyak $60 \%$ responden mengetahui bahwa kekurangan vitamin B dapat mengakibatkan gangguan saluran pernafasan, lalu sebanyak $66 \%$ responden mengetahui bahwa Vitamin B dapat melindungi dari infeksi COVID-19. Vitamin B tidak hanya membantu membangun dan memelihara sistem kekebalan yang sehat tetapi juga dapat berpotensi dapat mencegah atau mengurangi gejala COVID-19 atau pengobatan infeksi SARS-CoV-2 (7). Lalu, sebanyak 96\% responden mengetahui bahwa vitamin $C$ bekerja sebagai antioksidan sehingga dapat mencegah terjadinya infeksi Covid-19. Hasil tersebut sejalan dengan penelitian yang dilakukan oleh dhiani et al. di TK Aisyiyah Ledug (2020) yaitu sebesar 37,9\% responden mengetahui vitamin $\mathrm{C}$ sebagai antioksidan ${ }^{(29)}$. Sebanyak $76 \%$ responden mengetahui bahwa Dosis harian Vitamin C untuk pemeliharaan kesehatan maksimal 1000 mg/hari. Hasil tersebut melebihi penelitian yang dilakukan oleh dhiani et al. di TK Aisyiyah Ledug (2020) yaitu sebesar $27,6 \%$ responden mengetahui dosis maksimal harian vitamin $\mathrm{C}^{(29)}$. Hal ini menunjukkan responden pada penelitian ini memiliki pengetahuan tentang vitamin $\mathrm{C}$ lebih tinggi dibandingkan dengan responden pada penelitian dhiani et al. di TK Aisyiyah Ledug (2020). Vitamin C memiliki aktivitas antioksidan dan dapat mengurangi stres oksidatif dan peradangan, efek yang meningkatkan sintesis vasopresor, meningkatkan fungsi sel kekebalan tubuh, meningkatkan fungsi endovaskular, dan menyediakan modifikasi imunologis epigenetic ${ }^{(9)}$.

Sebanyak $78 \%$ responden mengetahui bahwa vitamin E dapat bekerja pada sistem daya tahan tubuh saat terinfeksi Covid-19. Pada mekanisme imun, vitamin E terlibat dalam mempertahankan atau meningkatkan aktivitas sitotoksik sel natural killer (NK) dan menghambat produksi PGE2 oleh makrofag sehingga secara tidak langsung melindungi fungsi sel-T (8). Vitamin D dapat melindungi paru dari infeksi COVID-19 diketahui oleh $43 \%$ responden. Persentase hasil tersebut melebihi penelitian sebelumnya di Surabaya yaitu sebesar $7,3 \%$ responden mengetahui vitamin D dapat melindungi dari infeksi (30).

Dari indikator-indikator tersebut, dapat diperoleh profil pengetahuan tentang vitamin sebagai peningkat sistem imun untuk upaya pencegahan COVID-19 pada pekerja industri di Kota Cilegon. Berdasarkan analisis data normalitas, pengetahuan menggunakan One Sample Kolmogorov Smirnov Test didapatkan hasil bahwa data pengetahuan berdistribusi normal sehingga pengetahuan dapat dikategorikan berdasarkan mean sebesar 11,87 dan standard deviation sebesar 1,884. Pengetahuan pekerja industri di Kota Cilegon dikelompokkan ke dalam 3 kategori yaitu $1 \%$ responden memiliki pengetahuan rendah $(<9,986), 32 \%$ responden berpengetahuan sedang $(9,986 \leq x<13,724)$, dan $67 \%$ responden berpengetahuan tinggi $(\geq 13,724)$. Berdasarkan hasil tersebut, mayoritas responden memiliki pengetahuan tinggi sejalan dengan penelitian yang dilakukan oleh Asri Wido Mukti pada warga Kebon Sari Surabaya (2020) yaitu sebanyak $54 \%$ responden berpengetahuan baik yang dalam penelitian ini sama dengan kategori pengetahuan tinggi(31). Hal tersebut menunjukkan reponden pada penelitian ini memiliki pengetahuan lebih tinggi dibandingkan responden pada penelitian Asri Wido Mukti pada warga Kebon Sari Surabaya (2020) (31). 
Pengetahuan dipengaruhi beberapa faktor yaitu pendidikan, pekerjaan, usia, minat, pengalaman, kebudayaan lingkungan sekitar serta informasi yang diperoleh (32). Pada penelitian ini pengetahuan tinggi mayoritas berpendidikan sarjana yaitu sebesar $11 \%$, namun reponden yang berpendidikan sarjana mayoritas berpengetahuan sedang sebesar $34 \%$. Pengetahuan sangat erat hubungannya dengan pendidikan, diharapkan bahwa dengan pendidikan yang semakin tinggi maka akan semakin luas pula pengetahuannya. Akan tetapi, bukan berarti seseorang yang berpendidikan rendah pasti berpengetahuan rendah pula (33). Pengetahuan vitamin sebagai peningkat sistem imun untuk upaya pencegahan COVID-19 didapatkan tidak hanya dari pendidikan formal tetapi juga didapat dari pengalaman serta lingkungan bermasyarakat (34).

Usia dapat memengaruhi penelitian. Dalam penelitian ini, usia dikelompokkan berdasarkan Kementerian Kesehatan Republik Indonesia. pengetahuan tinggi mayoritas berusia 26-35 tahun (dewasa awal) yaitu sebesar 9\%, namun reponden yang berusia 26-35 tahun mayoritas berpengetahuan sedang sebesar 13\%. Akan tetapi, menurut penelitian lain, usia bukan menjadi faktor penghambat karna terdapat faktor lain seperti keadaan fisiologi dan psikologis, serta adanya kemudahan dalam mendapatkan keterpaparan informasi yang sama (34).

\section{Kesimpulan}

Profil pengetahuan responden tentang vitamin sebagai peningkat sistem imun untuk upaya pencegahan COVID-19 di Kota Cilegon diperoleh $1 \%$ responden memiliki pengetahuan rendah, 32\% responden berpengetahuan sedang, dan $67 \%$ responden berpengetahuan tinggi. Dari hasil tersebut dapat disimpulkan bahwa pengetahuan responden tentang vitamin sebagai peningkat sistem imun untuk upaya pencegahan COVID-19 di Kota Cilegon adalah tinggi terhadap indikator pengetahuan tentang COVID-19, sistem imunitas, dan vitamin sebagai peningkat sistem imun untuk upaya pencegahan COVID-19 di Kota Cilegon.

\section{Daftar Pustaka}

1. KEMENKES RI. Info Corona Virus Archives »Info Infeksi Emerging Kementerian Kesehatan RI. (Accessed: 4 October 2020). Available at: https://covid19.kemkes.go.id/category/situasi-infeksi-emerging/info-corona-virus/\#. X3iLiNkzbMw

2. Lotfi, M., Hamblin, M. R. and Rezaei, N. 'Clinica Chimica Acta COVID-19: Transmission, prevention, and potential therapeutic opportunities', International Journal of Clinical Chemistry and Diagnostic Laboratory Medicine, 2020; 508(January):254-266.

3. Wang, J. and Du, G. 'COVID-19 may transmit through aerosol', Irish Journal of Medical Science, 2020;(5):5-6.

4. KEMENKES RI. 'Pedoman dan Pencegahan Coronavirus (COVID- 19)', KEMENTRIAN KESEHATAN REPUBLIK INDONESIA, 2020;1-214. 
5. Permenkes RI KMK No. HK.01.07/MENKES/382/2020 'Corona virus disease 2019', Peraturan Menteri Kesehatan Republik Indonesia, Nomor 9(Pedoman Pembatasan Sosial Berskala Besar dalam Rangka Percepatan Penanganan Corona Virus Disease 2019 (COVID-19); 2020.

6. Amalia, L., Irwan, I. and Hiola, F. 'Analisis Gejala Klinis Dan Peningkatan Kekebalan Tubuh Untuk Mencegah Penyakit Covid-19', Jambura Journal of Health Sciences and Research, 2020;2(2):71-76.

7. Shakoor, H. Feehan, J. Mikkelsen, K.Al Dhaheri, A. Ali, H. I. Platat, C. Ismail, L. C. Stojanovska, L. Apostolopoulos, V. 'Be well: A potential role for vitamin B in COVID-19', Maturitas, 2020;17-20.

8. Indriyani, A. and Andrianne, Y. 'COVID-19 dan Alternatif Penggunaan Vitamin dan Herbal', Bunga Rampai Artikel Penyakit Virus Korona ( COVID-19) Editor: Titik Respati; 2020

9. Bimantara, D. E. 'Peran Vitamin C dalam Pengobatan COVID-19 The Role of Vitamin C in Treatment Covid-19', 2020;9:1-4.

10. Badan POM RI, Buku Saku Suplemen Kesehatan Untuk Memelihara Daya Tahan Tubuh Dalam menghadapi COVID-19: Vitamin C. Badan Pengawasan Obat dan Makanan Republik Indonesia; 2020

11. Beard JA, Bearden A, Striker R. Vitamin D and the anti-viral state. J. Clin. Virol, $2011 ; 50: 194-200$.

12. Hewison M. An update on vitamin D and human immunity. Clin. Endocrinol. 2012;76:315-325

13. Greiller CL, Martineau AR. Modulation of the immune response to respiratory viruses by vitamin D. Nutrients 2015;7:4240-4270

14. Wei R, Christakos S. Mechanisms Underlying the Regulation of Innate and Adaptive Immunity by Vitamin D. Nutrients 2015;7:8251-8260

15. Coussens AK. The role of UV radiation and vitamin $D$ in the seasonality and outcomes of infectious disease. Photochem. Photobiol. Sci. 2017;16:314-338

16. Ardiaria, M. 'Peran Vitamin D dalam Pencegahan Influenza dan COVID-19', JNH (Journal of Nutrition and Health), 2020;8(2):79-85.

17. Holick MF. Vitamin D deficiency. N. Engl. J. Med. 2007;357:266-281.

18. Badan POM RI, Buku Saku Suplemen Kesehatan Untuk Memelihara Daya Tahan Tubuh Dalam menghadapi COVID-19: Vitamin D. Badan Pengawasan Obat dan Makanan Republik Indonesia; 2020

19. Badan POM RI, Buku Saku Suplemen Kesehatan Untuk Memelihara Daya Tahan Tubuh Dalam menghadapi COVID-19: Vitamin E. Badan Pengawasan Obat dan Makanan Republik Indonesia; 2020 
20. Badan Pengembangan Infrastruktur Wilayah, (Accessed: 15 February 2021). Available at: http://perkotaan. bpiw.pu.go.id/n/kota-otonom/2 .

21. Mahyadi, Gila! Ternyata 80 Persen Lebih Industri Kimia Nasional Ada di Kota Cilegon, KLHK Ungkap Ancaman untuk Lingkungan - bantenhits. (Accessed: 15 February 2021). Available at: https://bantenhits.com/2019/10/02/gila-ternyata-80persen-lebih-industri-kimia-nasional-ada-di-kota-cilegon-klhk-ungkap-ancamuntuk-lingkungan/

22. Notoatmodjo, S. 'Promosi Kesehatan dan IImu Perilaku'. Jakarta: Rineka Cipta; 2012

23. Rahayu, A.C. Penjualan vitamin Youvit tumbuh tiga kali lipat saat pandemi Corona. (Accessed: 15 February 2021). Available at: https://kesehatan. kontan.co.id/news/penjualan-vitamin-youvit-tumbuh-tiga-kali-lipat-saat-pandemicorona

24. Notoatdmodjo, S., 'Metodologi Penelitian Kesehatan'. Jakarta: Rineka Cipta. 2012.

25. Sugiyono., Metode Penelitian Kuantitatif, Kualitatif, dan R\&D. Bandung : Alfabeta, CV; 2017.

26. Arikunto, Suharsimi., Prosedur Penelitian.Jakarta : PT. Rineka Cipta; 2002.

27. Moudy, J. and Syakurah, R. A. 'Pengetahuan terkait usaha pencegahan Coronavirus Disease (COVID-19) di Indonesia', Higeia Journal of Public Health Research and Development, 2020;4(3):333-346.

28. Badan Pengawas Obat dan Makanan R.I., Pedoman Penggunaan Herbal dan Suplemen Kesehatan dalam Menghadapi COVID-19 di Indonesia. Badan Pengawas Obat dan Makanan R.I.; 2020.

29. Dhiani, B. A. et al. 'Peningkatan pengetahuan guru dan orang tua siswa taman kanak- kanak tentang penggunaan suplemen vitamin yang tepat', 2021;4(36): 161-168.

30. Suryadinata, R. V., Lorensia, A. and Wahyuningtyas, D. 'Studi Tingkat Pengetahuan Mengenai Vitamin D pada Pengemudi Becak di Surabaya', CoMPHI Journal: Community Medicine and Public Health of Indonesia Journal, 2020;1(1):15-21.

31. Mukti, A. W. 'Hubungan Pengetahuan terhadap Perilaku Penggunaan Suplemen Kesehatan Warga Kebonsari Surabaya di Masa Pandemi Covid-19', FARMASIS: Jurnal Sains Farmasi, 2020;1(1):20-25.

32. Mubarak, dkk. Promosi Kesehatan Sebuah Pengamatan Proses Belajar Mengajar Dalam Pendidikan. Jogjakarta: Graha IImu; 2013 
33. Wawan, A dan Dewi, M. Teori Dan Pengukuran Pengetahuan, Sikap Dan Perilaku Manusia. Yogyakarta: Nuha Medika; 2010

34. Wulandari, A. et al. 'Hubungan Karakteristik Individu dengan Pengetahuan tentang Pencegahan Coronavirus Disease 2019 pada Masyarakat di Kalimantan Selatan', Jurnal Kesehatan Masyarakat Indonesia,2020;15(1):42 